\title{
A NEWLY DEFINED SUBCLASS OF BI-UNIVALENT FUNCTIONS SATISFYING SUBORDINATE CONDITIONS
}

\author{
EMEKA PETER MAZI and TIMOTHY OPOOLA
}

\begin{abstract}
The purpose of our present paper is to introduce a newly defined subclass of bi-univalent functions satisfying subordinate conditions defined in the open unit disc. Coefficient estimates of $\left|a_{2}\right|$ and $\left|a_{3}\right|$ and the Fekete-Szegö problem for functions of this newly-defined class are established. The results of this work generalize some well known results.
\end{abstract}

MSC 2010. 30C45.

Key words. Bi-univalent function, coefficient bounds, Fekete-Szegö inequalities, pseudo-starlike function, Sakaguchi type function, subordination, TaylorMaclaurin coefficients.

\section{REFERENCES}

[1] Ş. Altınkaya and S. Yalçın, Coefficient bounds for a subclass of bi-univalent functions, TWMS J. Pure Appl. Math., 6 (2015), 180-185.

[2] Ş. Altınkaya and S. Yalçın, Coefficient estimates for two new subclasses of bi-univalent functions with respect to symmetric points, J. Funct. Spaces, 2015, Article 145242, 1-5.

[3] R.M. Ali, S.K. Lee, V. Ravichandran and S. Supramaniam, Coefficient estimates for bi-univalent Ma-Minda starlike and convex functions, Appl. Math. Lett., 25 (2012), $344-351$.

[4] K.O. Babalola, On ג-pseudo-starlike functions, J. Class. Anal., 3 (2013), 137-147.

[5] D.A. Brannan and T.S. Taha, On some classes of bi-univalent functions, Stud. Univ. Babeş-Bolyai Math., 31 (1986), 70-77.

[6] P.L. Duren, Univalent Functions, Springer Verlag, New York, 1983.

[7] B.A. Frasin, Coefficient inequalities for certain classes of Sakaguchi type functions, Int. J. Nonlinear Sci., 10 (2010), 206-211.

[8] S. G. Hamidi and J. M. Jahangiri, Faber polynomial coefficients of bi-subordinate functions, C. R. Math. Acad. Sci. Paris, 354 (2016), 365-370.

[9] S. Joshi, S. Joshi and H. Pawar, On some subclasses of bi-univalent functions associated with pseudo-starlike functions, J. Egyptian Math. Soc., 24 (2016), 522-525.

[10] M. Lewin, On a coefficient problem for bi-univalent functions, Proc. Amer. Math. Soc., 18 (1967), 63-68.

[11] E.P. Mazi and T.O. Opoola, On some subclasses of bi-univalent functions associating pseudo-starlike functions with Sakaguchi type functions, General Mathematics, 25 (2017), 85-95.

[12] G. Murugusundaramoorthy, N. Magesh and V. Prameela, Coefficient bounds for certain subclasses of bi-univalent functions, Abstr. Appl. Anal., 2013, Article 573017.

The authors thank the referee for his helpful comments and suggestions.

DOI: $10.24193 /$ mathcluj.2019.2.05 
[13] S.O. Olatunji and P.T. Ajai, On subclasses of bi-univalent functions of Bazilevic type involving linear and Salagean operator, Internat. J. Pure Appl. Math., 92 (2014), 645656.

[14] S. Owa, T. Sekine and R. Yamakawa, On Sakaguchi type functions, Appl. Math. Comput., 187 (2007), 356-361.

[15] K. Sakaguchi, On a certain univalent mapping, J. Math. Soc. Japan, 11 (1959), 72-75.

[16] S. Sumer Eker and B. Şeker, On $\lambda$-pseudo bi-starlike and $\lambda$-pseudo bi-convex functions with respect to symmetrical points, Tbilisi Math. J., 11 (2018), 49-57.

[17] H. M. Srivastava, A. K. Mishra and P. Gochhayat, Certain subclasses of analytic and bi-univalent functions, Appl. Math. Lett., 23 (2010), 1188-1192.

[18] T.S. Taha, Topics in Univalent Function Theory, Ph.D. Thesis, University of London, 1981.

[19] Q.-H. Xu, Y.-C. Gui and H. M. Srivastava, Coefficient estimates for a certain subclass of analytic and bi-univalent functions, Appl. Math. Lett., 25 (2012), 990-994.

[20] Q.-H. Xu, H.-G. Xiao and H. M. Srivastava, A certain general subclass of analytic and biunivalent functions and associated coefficient estimate problems, Appl. Math. Comput., 218 (2012), 11461-11465.

[21] P. Zaprawa, On the Fekete-Szego problem for classes of bi-univalent functions, Bull. Belg. Math. Soc. Simon Stevin, 21 (2014), 167-178.

[22] A. Zireh, S. Hajiparvaneh and S. Bulut, Faber polynomial coefficient estimates for a comprehensive subclass of analytic bi-univalent functions defined by subordination, Bull. Belg. Math. Soc. Simon Stevin, 23 (2016), 487-504.

Received July 3, 2018

Accepted October 15, 2018
University of Ilorin

Department of Mathematics

Ilorin, Nigeria

E-mail: emekmazi21@gmail.com

E-mail: Opoola_stc@yahoo.com 